\title{
Foraminiferal studies of eocen shekhan formation panoba section kohat northern Pakistan: implication for biostratgraphy and paleoenvirnments
}

\begin{abstract}
The present research is comprised of detail foraminiferal based biostratigraphy and paleoenvironmental understandings of Shekhan Formation (Early-Middle Eocene) Panoba section Pakistan. The foraminiferal studies exhibited detail for biostratigraphy which resulted in the interpretations of three planktonic-foraminiferal-biozones. Identified planktonic-foraminiferal-biozones include; (i) Nummulites globules (lower Eocene), (ii) Nummulites perporatus Biozone (middle Eocene), and (iii) Nummulites aturicus (middle Eocene). Furthermore, correlation of planktonic-foraminiferal-biozones with standard planktonic zonations have been done. In conclusion, various larger benthonic and smaller foraminifers of Lower-Middle Eocene interval have been identified. With the help of planktonic-benthonic ratio, the total foraminiferal abundance and their diversification/ preservation shallow to nerritic inner shelf environmental setting has been interpreted for Early-Middle Eocene Shekhan Formation.
\end{abstract}

Keywords: paleoenvironmental setting, eocene shekhan formation, panoba section.
Volume 3 Issue 5 - 2019

\author{
Sajjad Khan, Mehboob Ur Rashid, Naghmah \\ Haider
}

Geoscience Advance Research Laboratories, Geological Survey of Pakistan, Islamabad, Pakistan

Correspondence: Sajjad Khan, Geoscience Advance Research Laboratories, Geological Survey of Pakistan, Islamabad, Pakistan, Email pkpkgeo@gmail.com

Received: August 05, 2019 | Published: October II, 2019

\section{Introduction}

The studied section is situated in the North-Eastern side of the Kohat Plateau on Kohat Nizampur Road near Panoba Village (Figure 1). The Kohat Plateau forms the western margin of the Himalayan foreland folds and thrust belt. The sedimentary record of the Himalayan orogenic belt in North-Western Pakistan is well preserved in the Kohat foreland folds and thrust belt. ${ }^{1}$ The Kohat Plateau is linked to the North by Main Boundary Thrust (MBT) and to the south by Surghar Range Thrust (SRT). The eastern continuation of the Surghar Range Thrust is called the Salt Range Thrust, which is offset by right lateral movement along Kalabagh fault. On the eastern side, Indus River separates Kohat Plateau from Potwar Plateau. On the western side, the Kohat plateau is constrained by the Kurram fault. Total measured thickness of Panoba Section is $345 \mathrm{~m}$ and is comprised of sedimentary rocks of Paleocene-Miocene Figures $2 \& 3 .^{2}$ Shekhan Limestone was studied in detail at Panoba section. Shekhan formation is part of the Eocene sequence of the Kohat Plateau. ${ }^{2,3}$ The formation consists of limestone sequence in the lower part and alternating beds of limestone and shale in the upper part. ${ }^{2}$ The non-clastic facies of the Shekhan formation in the Northern part of the Kohat Basin, laterally changes to clastic facies of the Chashmai Formation ${ }^{4}$ in the west and to evaporites of the Bahadar Khel Salt and Jatta Gypsum in central and southern part of the basin. Furthermore, Shekhan formation rests conformably on the Panoba Shale and is composed of Yellowish grey, medium to thick bedded, nodular, highly bioturbated Limestone with shale partings. ${ }^{2}$ The formation contains abundant Eocene fossils. The Shekhan Formation is also exposed at Shekhan Nala South-East of Panoba Village and near the Tarkhobi village in Kohat. The main purpose of the present study is;

(i) To present detail study of existing formamineral species of Early-Middle Eocene Shekhan Formation; (ii) To identify foramineral based biostratigraphic zonations, and

(iii) Based on studied foramineral species to present paleoenvirenment of the formation.

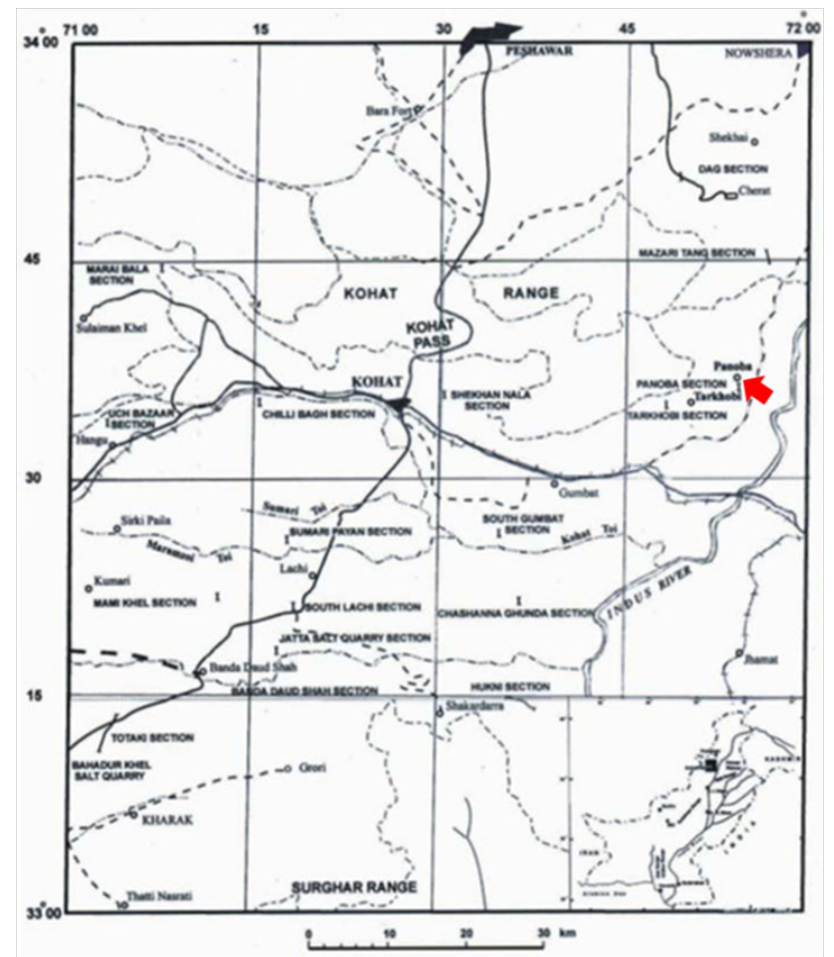

Figure I Location of study area. Red arrow showing location of studied section. 


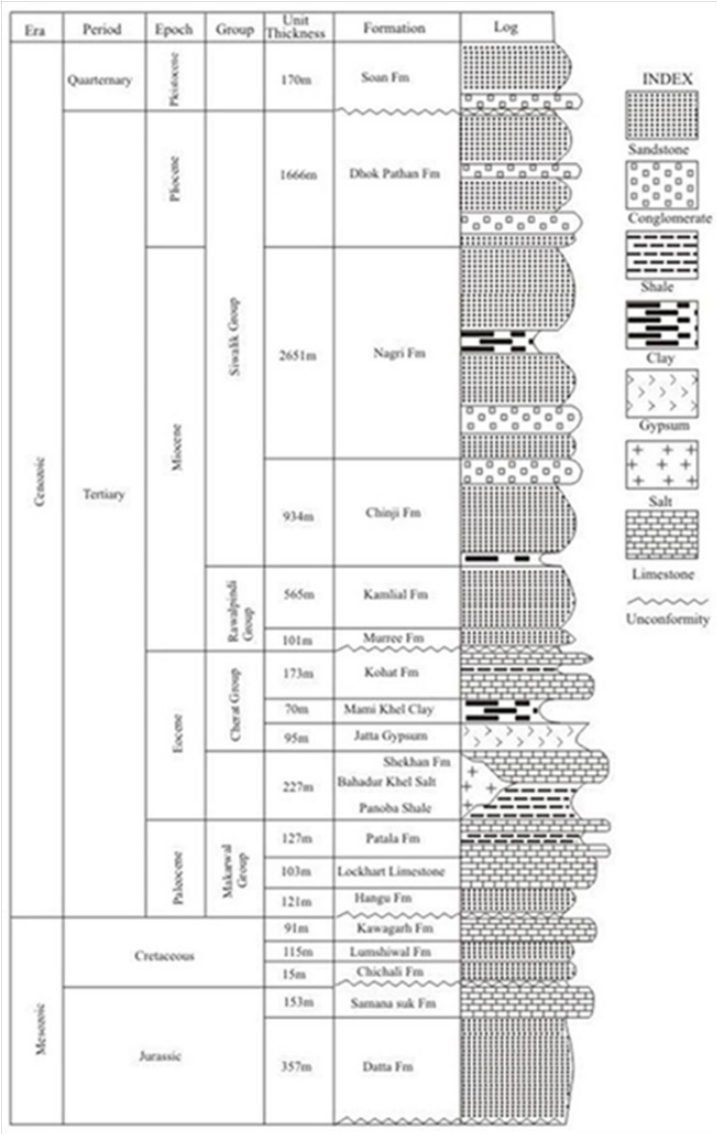

Figure 2 Stratigraphy of Kohat Plateau (modified after Kadri et al., 1995; Mesissner et al., 1974).
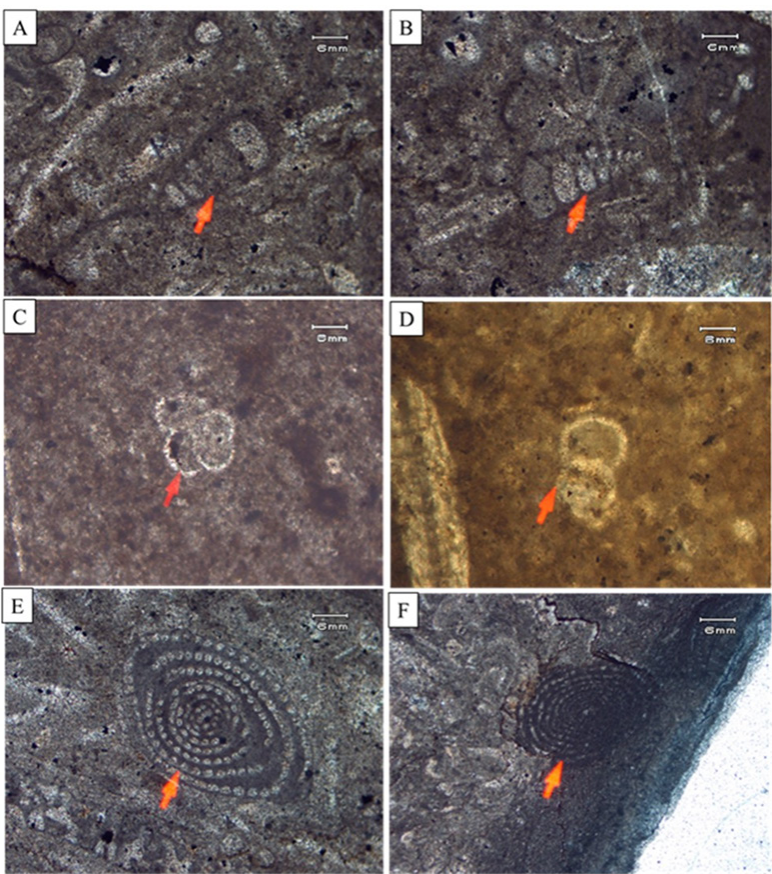

Figure 3 Identified species of foraminifera in Shekhan Formation Panoba section are; (A) specie: Chilogumbelina aff martini (Martini); side view, $P(x \mid 0)$, sample\# 7 (B) specie: Chilogumbelina victoriana (Beckmann, 1957); equatorial view, $\mathrm{P}(\mathrm{x} \mid 0)$, sample\# 7 (C) specie: Globogerina taroubaensis (Bronnimann, 1952); umbilical view, $P(x 20)$, sample\# 19 (D) specie: Subbotina lozanoi prolata (Bolli); P (x20), sample\# 16 (E) specie: Alveolina ludwingi (Reichel, 1936); P (x4), sample\# 7 (F) specie:Alveolina periloculinoides (Silvestri, I 939); $P(x 4)$, sample\# 7 .

\section{Stratigraphy of panoba section}

The Panoba section lies in the north eastern part of Kohat. The Kohat area is underlain by a thick sedimentary sequence of more than $61 \mathrm{~m}$ ranging in age from Jurassic to Pliocene. Due to severe tectonism, the rocks are highly folded and faulted. ${ }^{5,6}$ In the study area the rocks range in age from Paleocene to Miocene. In the study area due to tectonic activity rocks are folded and is existed in the form of east-west Panoba anticline. The Paleocene rocks constitute the core of the Anticline whereas the Miocene rocks lies on its flanks. The southern limb of this Anticline is faulted along which the Kohat Formation is thrust over the Murree Formation in the Footwall. The fault surface is characterized by Slickenside, fault breccias and the beds are steeply dipping in the hanging wall and footwall of the fault. The rocks exposed in Panoba section ranges in age from Paleocene to Miocene (Table 1).

Table I General Stratigraphy of Panoba section, Kohat Northern Pakistan

\begin{tabular}{llll}
\hline S. No & Formations & $\begin{array}{l}\text { Geological } \\
\text { age }\end{array}$ & Lithology \\
\hline I & $\begin{array}{l}\text { Kamlail } \\
\text { Formation }\end{array}$ & Miocene & Sandstone \\
2 & $\begin{array}{l}\text { Murree } \\
\text { Formation }\end{array}$ & Miocene & $\begin{array}{l}\text { Siltstone, fossiliferous, } \\
\text { Monotonous sequence of clay }\end{array}$ \\
3 & $\begin{array}{l}\text { Kohat } \\
\text { Formation } \\
\text { Kuldana }\end{array}$ & Eocene & Interbeds of limestone \& shale \\
4 & $\begin{array}{l}\text { Formations } \\
\text { Shekhan }\end{array}$ & Eocene & Shale, Marl \\
5 & $\begin{array}{l}\text { Formation } \\
\text { Panoba Shale }\end{array}$ & Eocene & Shale, limestone \\
7 & $\begin{array}{l}\text { Patala } \\
\text { Formation } \\
\text { Lockhart } \\
\text { Limestone }\end{array}$ & Paleocene & Shale \& marl, limestone \\
\hline
\end{tabular}

\section{Results}

Biostratigraphic results are based on identification of foraminiferal species which include twenty seven Larger Benthics, eight Smaller Benthic and four Planktonic Forams, from the outcrop samples of Shekhan Formation at Panoba section, Northern Kohat Plateau. Foraminiferal range distribution chart and biozonation is established using larger benthic Foraminera which include mostly Nummulites. Larger Benthic foraminifera can be used for correlation of shelf sequences where Planktonic Foraminifera are absent or in low abundance. Schaub, recognized four separate and partly overlapping boson sequences in Paleocene rocks of the Mediterranean based on Nummulites and Assilina (Table 2). Similarly Hottinger, ${ }^{7-9}$ also established Paleogene Alveolinids Biozonation (Figure 3). The Biozonation interval recognized on the basis of larger foraminifera provides a finer stratigraphic resolution than the circum globally recognized Planktonic foraminifera and calcareous nano Planktonic zones. In present study we have recognized thirthy nine foraminifera species recognized after ${ }^{10}$ which include Assilina dandotica (Figure 4B), A. pustulosa (Figure 4D), A.exponens (Figure 4C), A. pustulosa, A. subspinosa (Figure 4E), Discocyclina dispensa (Figure 4F), D. fortsi (Figure 5A), D. roberti (Figure 5B), D.scalaris (Figure 5C), D. sella (Figure 5D), D. undulata (Figure 5E), Lepidocyclina bikinensis (Figure 5E), Lockhartia pustulosa (Figure 6A), Miscellanea miscella (Figure 6B), Nummulites aturicus (Figure 6C), N. discorbina (Figure 6D), N. distans (Figure 6E), N. globulus (Figure 6F), N. mamillatus (Figure 7A), N. perforatus (Figure 7B), N. stellatus (Figure 7C), N. striatus (Figure 7D), Operculina canalifera (Figure 7E), Bigenerina 
sp. (Figure 7F), Articulina sagra (Figure 8A), Hauerina bradyi (Figure 8B), Quinqueloculina vulgaris (Figure 8C), Nodosaria nammalensis (Figure 8D), Nonionella sp. (Figure 8E), Pseudoglandulina caudigera (Figure 8F), Texularia sp. (Figure 8G), Chiloguembelina aff. Martini (Figure 3A), Chiloguembelina Victoriana (Figure 3B), Globigerina taroubaensis (Figure 3C), Subbotina lozanoi prolata (Figure 3D), Alveolina ludwingi (Figure 5E), Alveolina periloculinoides (Figure $3 \mathrm{~F}$ ) are as shown in the range distribution chart (Figure 2). Following the scheme of Schaub, (Table 2), three Nummulitic Biozones are established which include:

Table 2 Schaub's multiple biozonation charts for the Palaeogene based on Nummulites and Assilina compared with the Alveolina zones of Hottinger (1960) and the nannoplankton zones of Kapellos and Schaub (1975) and Cavalier (1975) (modified after Schaub, 198I).

\begin{tabular}{|c|c|c|c|c|c|c|c|c|}
\hline \multirow{3}{*}{ ЕРОСН } & \multirow{3}{*}{ Stage } & & \multicolumn{6}{|l|}{ Biozones } \\
\hline & & & \multicolumn{3}{|l|}{ Nummulites } & \multirow[b]{2}{*}{ Assilina } & \multirow[b]{2}{*}{ Alveolina } & \multirow[b]{2}{*}{ Nanoplankton } \\
\hline & & & $\begin{array}{l}\text { Group of } \mathbf{N} \\
\text { bronograties }\end{array}$ & $\begin{array}{l}\text { Group } \\
\text { of } \mathbf{N} \\
\text { Pertoratus }\end{array}$ & Others & & & \\
\hline Oligocene & & Lower & & & fichteli & & & Er. subdisticha \\
\hline \multirow[t]{4}{*}{ UPPER } & & PRIABONIAN & & & Fabiani & & $\begin{array}{l}\text { Neo } \\
\text { Alveolina }\end{array}$ & $\begin{array}{l}\text { I.Pseudoraduans } \\
\text { I.recurvus }\end{array}$ \\
\hline & BIARRITZIAN & & brongniarti & perforatus & ptutiari & & elongata & Ch.Oamaruensis \\
\hline & & UPPER & herbi & aturicus & bulstus & gigantea & & \\
\hline & LUTETIAN & MIDDLE 2 & scrdensis & crasus & & planospra & prorrecta & Disc. tari nodifer \\
\hline \multirow{5}{*}{ MIDDLE } & & MIDDLE I & gratus & beneharnesis & & spira spira & murieri & Chiphr.alatus \\
\hline & & LOWER 2 & laevigatus & $\begin{array}{l}\text { obesus } \\
\text { gallensis }\end{array}$ & & spira abrard & stipes & \\
\hline & & UPPER & manfred & campesinus & lormosus & major & violae & Disc.sublodoensi \\
\hline & & MIDDLE & praelaevigatus & $\begin{array}{l}\text { burd. } \\
\text { cantabricth }\end{array}$ & nitous & laxispira & daineli & \\
\hline & & $\begin{array}{l}\text { LOWER I } \\
\text { LOWER } 2\end{array}$ & planulatus & buragalensis & aff.larus & plana & obionga & Disc.ladoersis \\
\hline \multirow[t]{4}{*}{ LOWER } & $\begin{array}{l}\text { ILERDIAN } \\
\text { CUISIAN }\end{array}$ & UPPER & involutus & & laxus & adrianensis & trempina & Marth trbrachiatus \\
\hline & & $\begin{array}{l}\text { MIDDLE } 2 \\
\text { MIDDLE I }\end{array}$ & $\begin{array}{l}\text { exilis } \\
\text { robustiformis }\end{array}$ & perrotus & $\begin{array}{l}\text { globulus } \\
\text { zarcasonensis }\end{array}$ & $\begin{array}{l}\text { leymeriei } \\
\text { aff.Arenesis }\end{array}$ & $\begin{array}{l}\text { corbarira } \\
\text {-noussoulens }\end{array}$ & Disc.binodosus \\
\hline & & $\begin{array}{l}\text { LOWER } 2 \\
\text { LOWER I }\end{array}$ & fraasi & soatarus & $\begin{array}{l}\text { minervensis } \\
\text { deserti }\end{array}$ & $\begin{array}{l}\text { arenensis } \\
\text { prisca }\end{array}$ & $\begin{array}{l}\text { ellpsoidais } \\
\text { cucumtorms }\end{array}$ & $\begin{array}{l}\text { Marth contartus } \\
\text { Disc mutradiatus }\end{array}$ \\
\hline & & UPPER & & & & yvettae & levis & \\
\hline \multirow[t]{2}{*}{ UPPER } & THANETIAN & & & & & & & \\
\hline & & LOWER & & & & & primaeva & $\begin{array}{l}\text { Hel rededi Disc } \\
\text { gemmeus Hel Herpeli } \\
\text { Fasc lympanformis El } \\
\text { macelius Chiasm dancus }\end{array}$ \\
\hline LOWER & & DANIAN & & & & & & $\begin{array}{l}\text { Crupl terius Martial } \\
\text { mersus }\end{array}$ \\
\hline
\end{tabular}




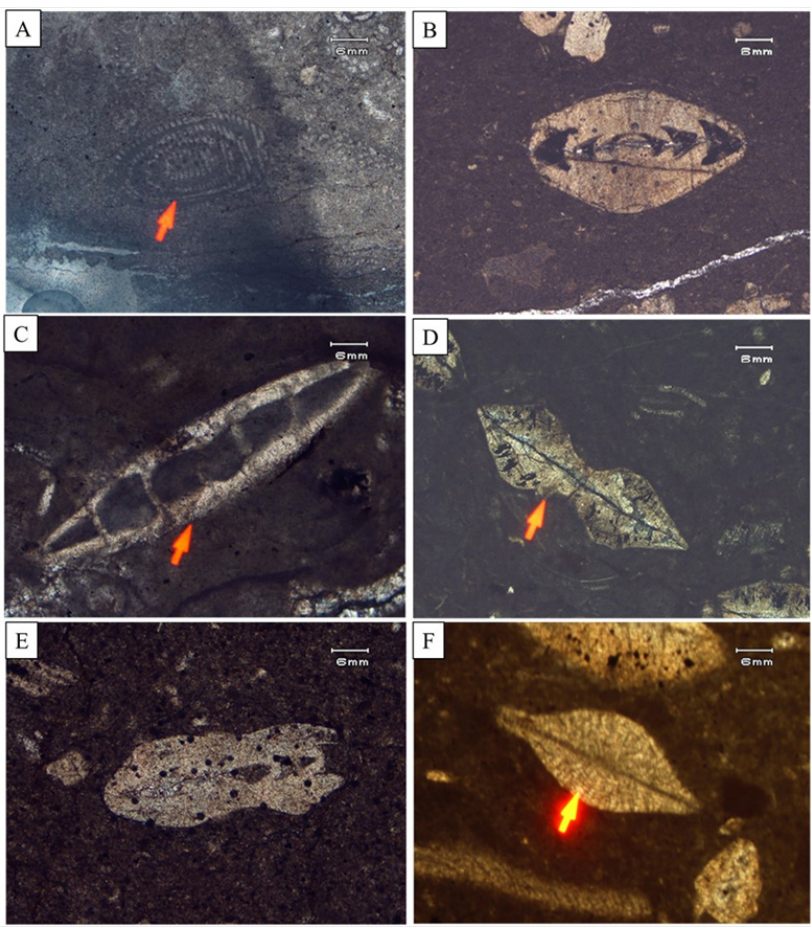

Figure 4 Identified species of foraminifera in Shekhan Formation Panoba section are; (A) specie: Alveolina terebrata (Silvestri, 939) $P(x 4)$, sample \# 7 (B) Specie: Assilina dandotica (Davies, 1937) P (x4), sample \# 4, II, 4 (C) specie: Assilina exponens (Sowerby, 1840) P (x4), sample \# 4, I4, 16 (D) specie: Assilina pustulosa (Doncieux, 1926) P (x4), sample \# 4 (E) specie: Assilina subspinosa (Davies and Pinfold, 1937) P (x|0), sample \# II (F) specie: Discocylina dispensa (Sowerby, I926) P(x4), sample \# II, |4-16, I8.
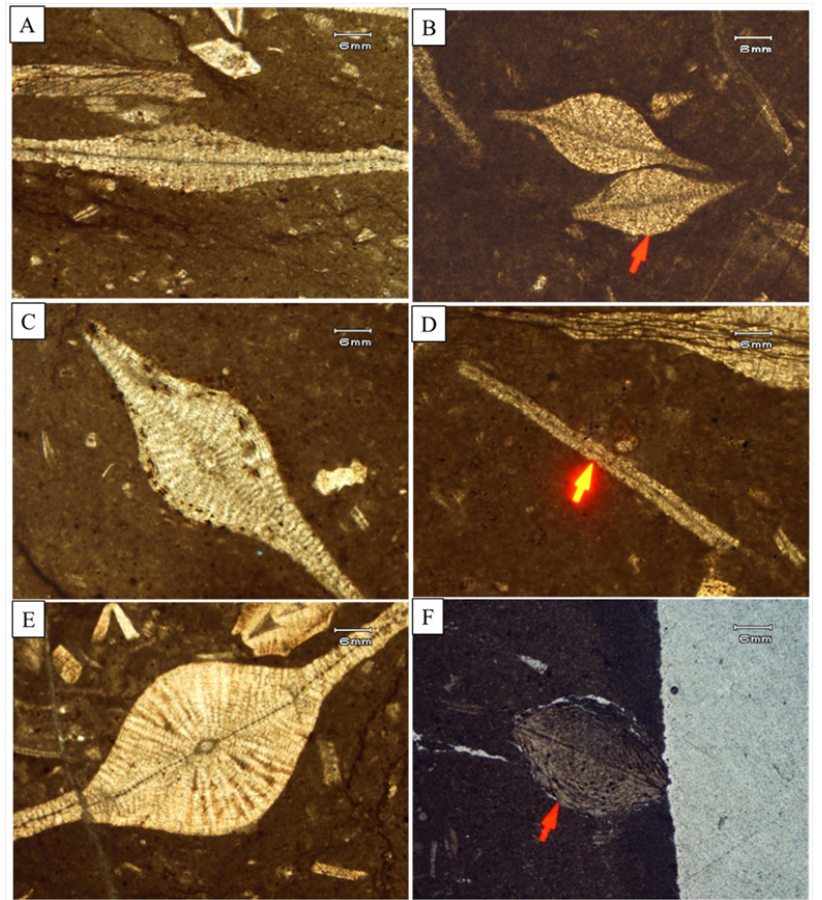

Figure 5 Identified species of foraminifera in Shekhan Formation Panoba section are; (A) specie: Discocyclina fortsi (d'Archaic, 958) P (x4), sample \# II, I4-I5 (B) specie: Discocyclina roberti (Douville, 1958) P (x4), sample \# 15, 18 (C) specie: Discocyclina scalaris (Schlumberger, 1958) P (x4), sample \# I I, I4-I5 (D) specie: Discocyclina sella (d'Archaic, I958) P (x4), sample \# I5 (E) specie: Discocyclina undulata (Nuttall, 1926) P (x4), sample \# I4 (F) specie: Lepidocyclina bikinensis (Cole, I954) P (x4), sample \# II.

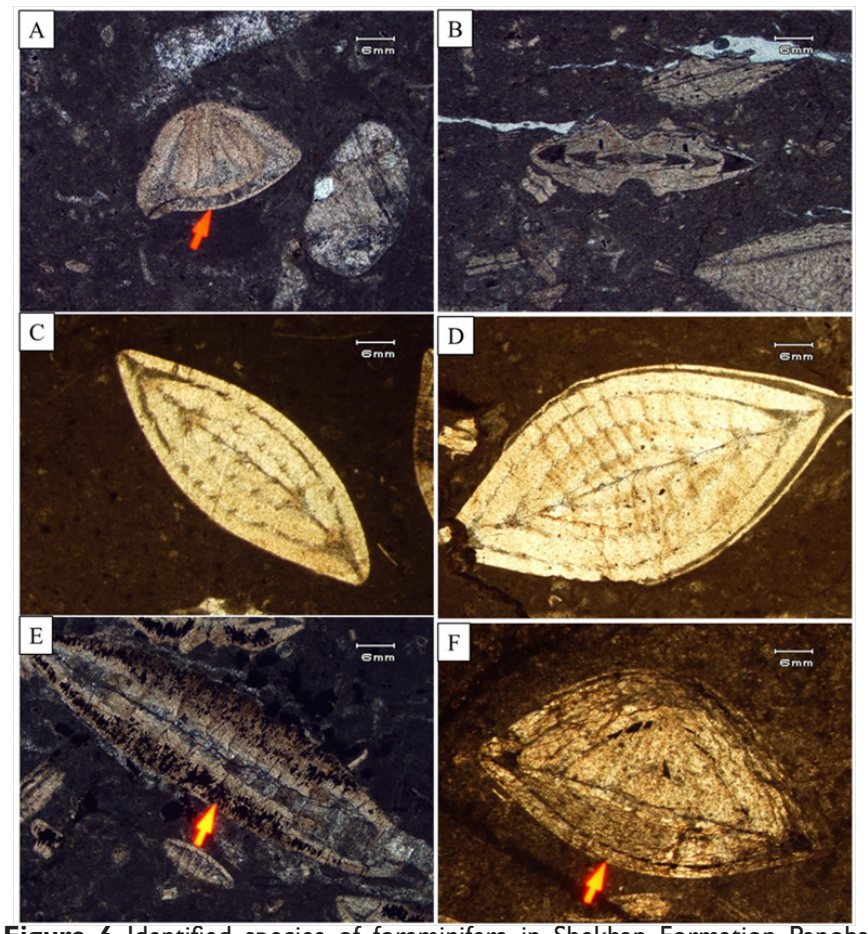

Figure 6 Identified species of foraminifera in Shekhan Formation Panoba section are; (A) specie: Lockhartia pustulosa (Smout, 954) P (x4), sample \# 7 , 19 (B) specie: Miscellanea miscella (d'Archaic and Haime, I854) P (x4), sample \# I I, I4, I7 (C) specie: Nummulites aturicus (Joly and Leymerie, 1962) P (x 10), sample \# 5, I 4 (D) specie: Nummulites discorbina (d'Archaic and Haime, I853) P (x4), sample \# 6, I2, I4 (E) specie: Nummulites distans (Deshayes, 1959) P (xI0), Sample \# 4, I I, I4, I 5 (F) specie: Nummulites globulus (Leymerie, I846) $\mathrm{P}(\mathrm{x} 4)$, Sample \# 4, 18.

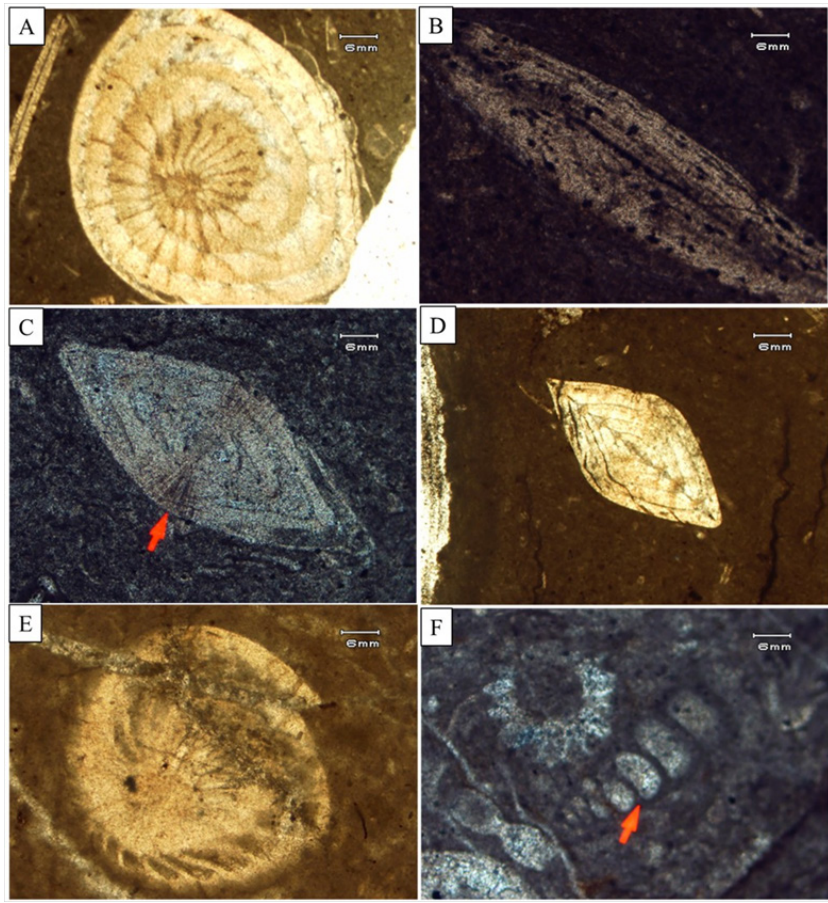

Figure 7 Identified species of foraminifera in Shekhan Formation Panoba section are; (A) Specie: Nummulites mamillatus (Fichtel Moll) P (x4), sample\# 4, I8 (B) specie: Nummulites perforatus (de Montfort, I808) P (xI0), sample\# I I (C) specie: Nummulites stellatus (Roveda, I96I) P (xI0), sample\# 4, I2 (D) specie: Nummulites striatus (Bruguiere, I792) P (x4), sample\# I4 (E) specie: Operculina canalifera (d'Archaic and Haime, 1853) P (x20), sample\# 17 (F) specie: Bigenerina sp. (d’Orbigny, I826) P (x|0), sample\# 7 


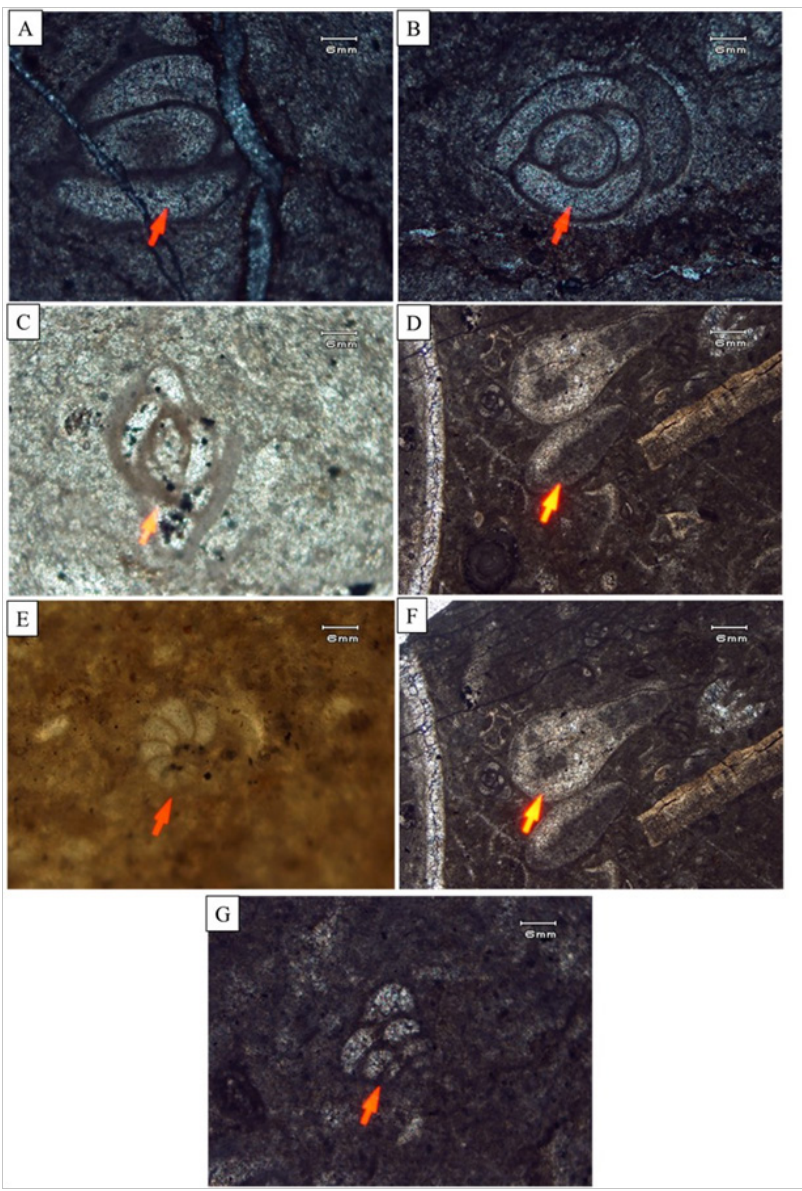

Figure 8 Identified species of foraminifera in Shekhan Formation Panoba section are; (A) specie: Articulina sagra (d'Orbigny, 1826) P (x20), sample\# I2 (B) Specie: Hauerina bradyi (Cushman, 1946) P (x20), Sample \# I2 (C) Specie: Quinqueloculina vulgaris (d'Orbigny, 1826) P (x20), sample\# 7, 12 (D) specie: Nodosaria nammalensis (Haque, 1956) P (x4), sample\# 7 (E) species: Nonionella sp. (Haque, I956) P (xI0), sample\# 16, I7 (F) species: Pseudoglandulina caudigera (Schwager, I883) P (x4), sample\# 7 (G) species: Textularia sp. (Haque, 1956) P (x20), Sample\# 7.

\section{Nummulites globulus Biozone}

Nummulites globulus specie is recognized in sample Sf 4 (Figure $6 \mathrm{~F})$. The base of this zone is marked by first occurrence of Nummulites globulus, Assilina dandotica and Nummulites stellatus. Associated fauna includes Discocyclina dispensa, D. roberti, Assilina exponens, A. dandotica, A. pustulosa, Miscellanea miscella, Nummulites distans, N. carteri, N. stellatus, N. vredenburgi and Lockhartia pustulosa. Nummulites globulus Biozone marks the deposition of Limestone in Lower Eocene (Ilerdian stage).

\section{Nummulites aturicus Biozone}

Nummulites aturicus is recognized by Schaub and Racey ${ }^{10}$ as an important Nummulitid. The base of $\mathrm{N}$. aturicus Biozone is taken at the first occurrence of Nummulites aturicus in sample Sf 5 (Figure 6C). In our present study and it extends up to Sf 14. In Shekhan Formation Nummulites aturicus is often associated with Discocyclina dispensa, D. fortsi, D. scalaris, D. undulata, Assilina exponens, A. dandotica, Miscellanea miscella, Nummulites distans, N. discorbina, N. mamillatus and N. striatus. The range of Nummulites aturicus is Lutetian to Early Biarritzian.

\section{Nummulites perforatus Biozone}

Racey ${ }^{10}$ recognized Nummulites perforatus in Eocene rocks of Oman and gave Biarritzian age to this particular biozone. The base of this biozone is taken at the first occurrence of Nummulites perforatus in Shekhan formation sample Sf 11 (Figure 7B). The associated fauna in Shekhan Formation includes Discocyclina dispensa, D. fortsi, D scalaris, Assilina dandotica, A. subspinosa, Miscellanea miscella, Nummulites distans and Lepidocyclina bikinensis. The Biozonation shows that deposition of outcrop of Shekhan Formation in Panoba Section, Northern Kohat Plateau started in Lower Eocene (Ilerdian) and ended in Middle Eocene (Biarritizan)

\section{Discussions}

Paleo-environmental identification is generally based on the qualitative and quantitative analysis of planktonic, smaller benthic and larger benthic foraminifers. ${ }^{11,12}$ The quantitative approach is based on the carefully assigned frequency classes mentioned in the distribution chart with their respective ranges. The fauna gradually changes with water depth mainly in term of relative abundance rather than generic or species composition of the assemblage. The larger benthic foraminifers are the most common constituents of the late Paleoceneearly Eocene carbonate platforms ${ }^{13}$ and they are of tropic in nature, lived within the shallow photic zone in symbiosis with algae. Thus the integrated analysis of the quantitative distribution of the larger benthic, smaller benthic and planktonic foraminifers allowed us to reconstruct paleoenvironmental history for the Shekhan Formation at Panoba Section as follow. The over-all formation shows very high ratio (sample wise) of larger benthic, smaller benthic and very low ratio of planktonic foraminifers, which suggests shallow neritic inner shelf environment for the deposition of Shekhan formation in Panoba section Kohat. ${ }^{14-19}$

\section{Conclusion}

i. The Panoba section of Kohat, NWFP Pakistan has an excellent exposure of Lower to Middle Eocene carbonate sequence of Shekhan formation.

ii. The measured section is lithologically composed of medium to thin bedded gray to yellowish gray limestone interbedded with shale.

iii. Formation has yielded rich assemblages of foraminifers, which lead to the identification of four planktonic, eight smaller and twenty seven larger benthonic species, which include Assilina dandotica, A. pustulosa, A. exponens, A. pustulosa, A. subspinosa, Discocyclina dispensa, D. fortsi, D. roberti, D. scalaris, D. sella, D. undulata, Lepidocyclina bikinensis, Lockhartia pustulosa, Miscellena miscella, Nummulites aturicus, N. discorbina, N. distans, N. globulus, N. perforatus, N. stellatus, N. striatus, N. mamillatus, Operculina canalifera, Bigenerina sp., Articulina sagra, Hauerina bradyi, Quinqueloculina vulgaris, Nodosaria nammalensis, Nonionella sp., Pseudoglandulina caudigera, Texularia sp., Chiloguembelina aff. martini, Chiloguembelina victoriana, Globigerina taroubaensis and Subbotina lozanoi prolata as shown in the range distribution chart.

iv. Among recorded foraminifers smaller benthic are long range and are less significant for Stratigraphic determinations except few species, while larger benthic are abundant and have lead to the establishment of three biozones i.e. (Nummulites aturicus, N. perforatus, N. globulus). Planktonic foraminifers were found stratigraphically not significant. 
v. Lower to Middle Eocene age has assigned to the Shekhan formation on the basis of present research on the recorded foraminifers. ${ }^{10}$

vi. Paleo-environmental interpretations based on the distribution of studied foraminifers have yielded shallow neritic inner shelf environment for the deposition of Shekhan formation at Panoba Section Kohat.

\section{Acknowledgments}

None.

\section{Conflict of interest}

The authors declare that there is no conflict of interest.

\section{Funding}

None.

\section{References}

1. Pivnik DA, Wells NA. The Transition from Tethys to the Himalayas as recorded in northwest Pakistan. Geological society of American Bulletin. 1996;108(10):1295-1373.

2. Shah SMI. Stratigraphy of Pakistan. Geological Survey of Pakistan, Memoir. 2009;22:381.

3. Shah IS, Khan IA. Lexicon of the stratigraphy of Pakistan. Geological Survey of Pakistan Memoir. 2016;23:411.

4. Tanoli SK, Abbasi IA, Rehman O, et al. Early Cenozoic delticsedimentation in Kohat Basin. Abstract, First south Asian Geol. Cong. Islamabad. 1992.

5. Meissner CR, Master JM, Rashid MA, et al. Stratigraphy of Kohat quadrangle, Pakistan. United States Geological Survey, professional paper. 1974;716.

6. Meissner CR, Master JM, Rashid MA, et al. Stratigraphy of Kohat Quardangle,west Pakistan. USGS proj. Rep. (IR) PK-20. 1968;1-86.

7. Hottinger L. The Paleocene and earliest Eocene foraminiferal family Miscellaneidae: neither nummulitids nor rotaliids. Noteb Geol. 2009;6:1-41.

8. Hottinger L, Schaub H. Zur Stufeneinteilung das Paleocaens uns das Eocaens. Einfu"hrung der Stufen Ilerdien und Biarritzien. Eclogae Geol Helv. 1960;53:453-479.
9. Hottinger L. Foraminiféres operculiniformes. Mémoire du Museum de National de Histoire naturelle, Paris. 1977a;40:1-159.

10. Racey A. Biostratigraphy and Palaeobiogeographic significance of Tertiary Nummulitids (Foraminifera) from Northern Oman. In: Simmons MD, Editors. Micropalaeontology and Hydrocarbon Exploration in the Middle East. Chapman \& Hall. 1994;343-370.

11. Behforouzi E, Safari A. Biostratigraphy and paleoecology of the Qom Formation in Chenar area (northwestern Kashan), Iran. Revista Mexicana de Ciencias Geológicas. 2011;28(3):555-565.

12. Naggapa Y. Foraminiferal biostratigraphy of the Cretaceous-Eocene succession of India-Pakistan-Burma region. Micropaleotology. 1959;5(2):145-192.

13. Hottinger L, Smeeni SJ, Butt AA. Emendation of Alveolina vredenburgi Davies and Pinfold, 1937 from the Surghar range, Pakistan. Dela-Opera SAZU 4. Razr. 1998:34:155-163.

14. Davies LM. Notes on the geology of the Kohat, with reference to the homotaxial position of the salt marl at Bahadur Khel. Asiatic Society of Bengal Journal and Proceedings, New Series. 1926;20:207-224.

15. Eames FE. A contribution to the study of the Eocene in western Pakistan $\&$ western India. The geology of standard sections in the western Punjab and in the Kohat District. Quarterly Journal of the Geological Society of London. 1952;107:159-171.

16. Eames FE. A contribution to the study of the Eocene in western Pakistan \& western India. Discussion of the faunas of certain standard sections, and their bearing on the classification and correlations of the Eocene of western Pakistan and western India. Quarterly Journal of the Geological Society of London. 1952;107:173-200.

17. Eames FE. Eocene in western Pakistan and western India; bearing on the classification and correlation of the faunas of the certain standard sections in Pakistan and western India. Contribution to the study of the Eocene. Quarterly Journal of the Geological Society of London. 1950;107:173200.

18. Rahaghi A. Tertiary faunalAssemblage of Qum-Kashan, Sabzewar and Jahrum area: National Iranian Oil Company. Geological Laboratories, Publication 8. 1980.

19. Rahaghi A. Contribution to the study of some large foraminifera from Iran. Iranian National Petroleum Society Micropaleontology Laboratory, Publication. 1976;6:1-79. 